\title{
Kivi (Actinidia deliciosa L.)'de Ozon Gazı Uygulamasının Hasat Sonrası Kalite Üzerine Etkileri
}

\section{Kübra YAŞAR 1 , M. Ufuk KASIM ${ }^{2},{\operatorname{Rezzan~} \mathrm{KASIM}^{3}}^{2}$}

${ }^{1}$ Kocaeli Üniversitesi, Fen Bilimleri Enstitüsü, 41001, Umuttepe, Kocaeli, ${ }^{2,3}$ Kocaeli Üniversitesi, Arslanbey Meslek Yüksekokulu, 41285 , Kartepe, Kocaeli.

${ }^{1}$ https://orcid.org/0000-0002-5311-9553, ${ }^{2}$ https://orcid.org/0000-0003-2976-7320, ${ }^{3}$ https://orcid.org/0000-0002-2279-4767

$\bowtie:$ rkasim@kocaeli.edu.tr

\section{ÖZET}

$\mathrm{Bu}$ araştırmada ozon gazının kivi muhafazası sırasında kalite kayıplarını geciktirmedeki etkileri incelenmiştir. $\mathrm{Bu}$ amaçla depolama öncesi, kivi meyvelerine $0.3 \pm 0.02 \mu \mathrm{L} \mathrm{L}^{-1}$ dozundaki ozon gazı dört farklı sürede $(6,12,24,48$ saat) uygulanmıştır. Uygulama sonrası kiviler $1 \pm 1^{\circ} \mathrm{C}$ sicaklık ve $\% 80-85$ oransal nem koşullarında 6 ay depolanmıștır. Kivi meyvelerinde depolama süresince aylık aralıklarla; ağırlık kaybı, suda çözünür toplam kuru madde (SÇKM), meyve eti sertliği, meyve kabuk rengi $\left(L^{*} a^{*} b^{*}\right)$, fruktoz, glikoz, sakkaroz, toplam şeker, tat puanlaması, titre edilebilir asit miktarı, elektrolit sızıntısı ve toplam klorofil miktarı analizleri yapılmıştır. Elde edilen sonuçlara göre 12 saatlik ozon gazı uygulaması; meyve eti sertliği, ağırlık kaybı, titre edilebilir asit miktarı ve SÇKM miktarı bakımından en iyi uygulama olmuştur. Ancak bu uygulama elektrolit sızıntısının artmasına neden olmuştur. Ozon gazı renk üzerinde olumlu ya da olumsuz bir etki oluşturmamıştır. Ozon uygulanan kivi meyvelerinde kontrole göre sakarozun daha yavaş parçalanması nedeniyle ozon uygulamalarının olgunlaşmayı geciktirici etkisinin olduğu söylenebilmektedir.

\section{Araştırma Makalesi}

\author{
Makale Tarihçesi \\ Geliş Tarihi : 29.01.2020 \\ Kabul Tarihi : 17.03 .2020
}

Anahtar Kelimeler

Kalite

Olgunlaşma

Kivi

Ozon gazı

Soğukta muhafaza

\section{Effects of Ozone Gas Application on Postharvest Quality in Kiwifruits (Actinidia deliciosa L.)}

\section{ABSTRACT}

Objective of this study was to determine the effect of ozone gas on to delay quality losses during the storage of kiwifruit. For this aim, kiwifruits were treated with $0.3 \pm 0.02 \mathrm{\mu L} \mathrm{L}^{-1}$ dose of ozone at the four different times $(6,12,24,48$ hours) before storage. After ozone treatments, the kiwifruits were stored at $1 \pm 1^{\circ} \mathrm{C}$ temperature and $80^{-}$ $85 \%$ relative humidity for six months after the treatments. Weight loss, total soluble solids, fruit firmness, fruit flesh color $\left(L^{*} a^{*} b^{*}\right)$, fructose, glucose and sucrose content, total sugar, taste point, titratable acidity, electrolyte leakage and total chlorophyll content were determined at monthly intervals, during storage. According to the results, the ozone treatment at 12 hours was the best in terms of fruit firmness, weight loss, titratable acids, and total soluble solids. While, this treatment caused increasing electrolyte leakage, overall, the ozone gas treatments did not create any negative or positive effect on the color of kiwifruit. Also, it could be said that the ozone treatments delayed the ripening of kiwifruit because of its decreasing effect on sucrose breakdown compared to control.

\section{Research Article}

$\begin{array}{ll}\text { Article History } & \\ \text { Received } & : 29.01 .2020 \\ \text { Accepted } & : 17.03 .2020\end{array}$

\section{Keywords}

Quality

Ripening

Kiwifruit

Ozone gas

Cold storage

To Cite : Yaşar K, Kasım MU, Kasım R 2020. Kivi (Actinidia deliciosa L.'de Ozon Gazı Uygulamasının Hasat Sonrası Kalite Üzerine Etkileri. KSÜ Tarım ve Doğa Derg 23 (4): 788-797. DOI: 10.18016/ksutarimdoga.vi.681591.

\section{GİRIŞ}

Subtropik meyveler içerisinde yer alan kivi (Actinidia deliciosa L.), askorbik asit (C vitamini;92.7 mg $100 \mathrm{~g}^{-1}$ ) bakımından zengin olduğu için tüketiciler tarafından son ylllarda oldukça fazla tercih edilmektedir (Garcia ve ark., 2012, USDA, 2018). Besin değerinin yüksek olması sayesinde kivi üretimine olan ilgi de her geçen gün artmaktadır. Kivi üretiminde dünyada ilk sırayı 2 390287 ton ile Çin almakta, bu ülkeyi İtalya ve Yeni Zelanda takip etmektedir. Türkiye ise 43950 ton ile 8 . sirada yer almaktadır (FAO, 2018).

Kivi üretimi ve tüketiminin artması ile beraber, hasat 
sonrası oluşan kayıplar ve bunların önlenmesi de önem kazanmıştır. Bu kayıplar düşme, ezilme ve yaralanma gibi fiziksel nedenlerle; yaşlanma, kartlaşma, su kaybı ve buruşma gibi fizyolojik nedenlerle veya mantar, bakteri ve zararliların oluşturduğu patolojik nedenlerle meydana gelmekte (Karaçalı, 2014) olup, miktarının ürünlere göre değişmekle beraber \%10-30 arasinda olduğu belirtilmiştir (Sholberg ve Conway, 2016).

Hasat sonrası oluşan bu kayıpları en aza indirebilmek için; sıcaklık uygulamaları (Bal, 2009), gama ışınları (Dinçer ve Topuz, 2006), UV-C uygulamaları (Bal, 2009), ozon uygulamaları (Feliziani ve ark., 2014;), uçucu (esansiyel) yağ uygulamaları (Servili ve ark., 2017; Yılmaz ve ark., 2019;) kullanılmaktadır. Ozon; bakteri, mantar ve virüsler üzerinde oksitleyici etki gösterdiğinden, gıda sanayinde önemli oranda kullanılmaktadır. Ozon klora göre \%52 daha etkili olmakta ve daha geniş bir mikroorganizma çeşitliliğini baskı altına alabilmektedir. Ozonun etkisi, hücre duvarlarinin oksitlenmesi yoluyla mikroorganizmaların öldürülmesi şeklindedir (Yıldız ve Yangllar, 2014). Ozon tarım ürünlerinde özellikle yüzeyde bulunan mikroorganizmaların yok edilmesi amacı ile kullanılmakta (Çelikel, 2018) olup, birçok üründe farklı şekillerde uygulama alanı bulmuştur. Bazı ürünlerde gaz formunda fumigasyon amaçlı uygulanırken bazı ürünlerde ozonlanmış su ile yıkama uygulamaları da yapılmaktadır (Savaş ve ark., 2014).

Taze meyve ve sebzelerin, nem içeriğinin yüksek olması, içerdikleri enzimler ve fenolik bileşikleri nedeniyle ozonun olumsuz etkileri de olabilmektedir. Özellikle meyve renginde açılmaya neden olması en önemli sorunudur (Çağatay, 2006).) Bu yüzden her bir ürün için ayrı ayrı denenerek, uygun doz ve sürelerin belirlenmesi gerektiği bildirilmektedir (Souza ve ark., 2018).
Bu çalışmanın amacı; doğal kaynaklı bir ürün olan ve hızlı bir şekilde parçalanarak ortamda oksijene dönüşebilen ozon gazının, farklı sürelerde uygulamasının, kivi muhafazasında kalite kayıplarını geciktirmedeki etkisini incelemektir.

\section{MATERYAL ve YÖNTEM}

Denemede kullanılan Hayward CL8 çeşidi kivi (Actinidia deliciosa L.) meyveleri Yalova ili Altınova ilçesinde bir üreticiden temin edilmiştir. Üretici bahçesindeki omcalar altı yaşlı olup, 5x4 m aralık mesafesinde dikilmiştir. Bahçe pergola telli terbiye sistemine sahip olup, mini-spring sulama sistemi ile sulanmaktadır. Bu bahçeden kivi meyveleri, ticari hasat döneminde (SÇKM: \%7,5-8 meyve eti sertliği; 8 $\mathrm{N})$ toplanmıştır. Hasattan sonra kivi meyveleri 1 saat içerisinde laboratuvara nakledilerek $0^{\circ} \mathrm{C}$ sıcaklıkta, başlangıç meyve iç sıcaklığı $\left(14^{\circ} \mathrm{C}\right), 4^{\circ} \mathrm{C}^{\prime} y e$ düşünceye kadar (yaklaşık 10 saat) durgun hava ile ön soğutma yapılmıştır.

Ozon Uygulamaları: Homojen bir şekilde gruplara ayrılan kivilerden bir grubu hiçbir uygulama yapılmadan kontrol olarak ayrılmış, diğer gruplara ise 5-10 g ozon/saat (hava beslemeli) ozon jeneratörü (Emsal EMS-OGN-5OOO) kullanılarak ozon gazı uygulanmıştır. Ozon uygulamaları ürünün depolama sıcaklığı olan $1^{\circ} \mathrm{C}$ sıcaklıkta yapılmış olup, ortamdaki ozon konsantrasyonunun belirlenmesi ve jeneratörün kontrolünü sağlamak amacı ile ozon ölçüm cihazı (EMS.O3 control) kullanılmıştır. Denemede kullanılan ozon gazı uygulama düzeneği Şekil 1'de gösterilmiştir. Yapılan çalışmada, kullanılan dozun belirlenmesi için literatür incelenerek yaş meyve ve sebzelerde iyi sonucu $0,3 \pm 0,02 \mu \mathrm{L} \mathrm{L} \mathrm{L}^{-1}$ dozunun verdiği görülmüş (Alexandre ve ark., 2011) ve bu doz kivilere dört farklı süreyle $(6,12,24$ ve 48 saat) uygulanmıştır.

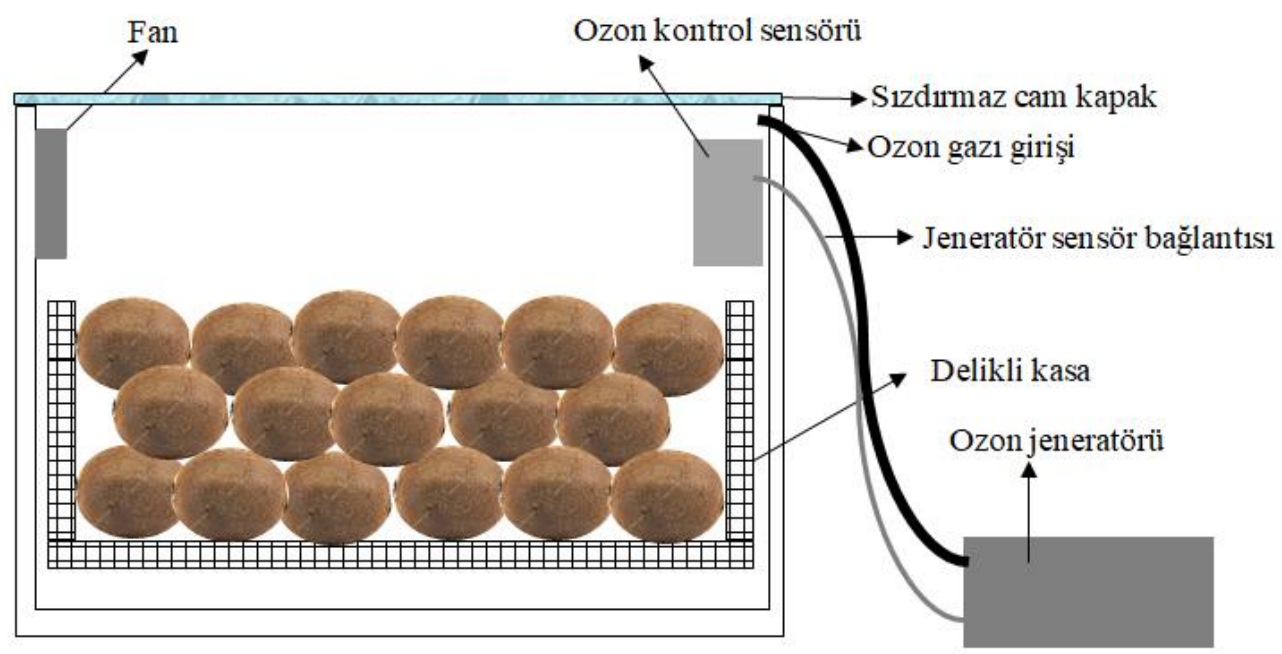

Şekil 1. Ozon uygulama düzeneğinin şematik görünümü Figure 1. Schematic view of the ozone application device 
Ambalajlama ve Depolama: Ozon gazı uygulamalarından sonra kivi meyveleri köpük tabaklara, her birinde 6 adet meyve olacak şekilde yerleştirilmiş ve 12 micron kalınlığında standart bir streç filmle sarılmıştır. Ambalajlanan ürünler kasalar içerisinde $1 \pm 1^{\circ} \mathrm{C}^{\prime}$ de \%80-85 oransal nem içeren depoda 6 ay süreyle depolanmıştır. Deneme başlangıcında ve aylık periyodlarda depodan alınan kivilerde meydana gelen değişimleri gözlemlemek amacı ile aşağıdaki ölçüm, gözlem ve analizler yapılmıştır.

Ă̆grlık kaybl; Depolama süresince oluşan ağırlık kaybı, başlangıç değerlerine oranlanarak, (\%) olarak hesaplanmıştır. Suda Ç̈̈zünür Toplam Kuru Madde (SCKM) Miktarı: Atago Pal-3 marka dijital refraktometreyle ölçülerek sonuçlar (\%) olarak verilmiştir. Meyve eti sertliği: Shimadzu EZ-LX marka tekstür analiz cihazının $6 \mathrm{~mm}$ çaplı iğne (piercing) ucuyla ölçülmüş ve sonuçlar Newton (N) olarak belirlenmiştir. Elektrolit sızıntısı: Kasım ve Kasım (2015)'in kullandığı yöntem kullanılarak ölçülmüştür. Titre edilebilir asitlik miktarı: sitrik asit cinsinden (\%) olarak hesaplanmıştır. Şeker Analizleri: Şeker analizi için $3 \mathrm{~g}$ meyve alınmış, üzerine $10 \mathrm{ml}$ saf su konularak homojenize edilmiş ve kaba filtre kağıdından süzüldükten sonra enjektör yardımıyla naylon 66 şırınga filtresinden geçirilerek yüksek basınçlı sıvı kromatografi cihazına (HPLC, Agilent 1260) enjekte edilmiştir. Şeker ölçümleri için Karbonhidrat 4.6 × 150 mm 5-Micron kolonundan yararlanılmış, mobil faz olarak Asetonitril : su (75:25) karışımı kullanılmıştır. Kolon sıcaklığı ortam sicaklığında olup, cihazın akış

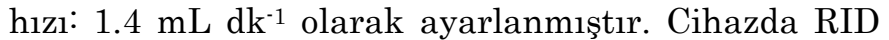
(Refractive index dedector) dedektörü ile $35^{\circ} \mathrm{C}$ sıcaklıkta okuma yapılmıştır. Klorofil ölçümü:Klorofil analizleri Mencarelli ve Saltveit (1988)'e göre yapılmıştır. Tat puanlaması: Kivilerin yeme kalitesi puanlamasi; tat, doku, aroma ve liflilik kriterlerine göre 5 kişiden oluşturulan jüri tarafından 1-5 skalasina göre (1:Kötü-5:Mükemmel) değerlendirilmiştir. Başlangıçta kiviler çok ekşi olmasindan dolayı tat puanlaması 2. aydan itibaren yapılmıştır. Meyve kabuğu rengi: Kivi meyvelerinin kabuk kısmında renk ölçümleri Minolta CR-400 renk ölçüm cihazı kullanılarak, $L^{*}, a^{*}$ ve $b^{*}$ renk değerleri ölçülmüştür. Deneme üç tekerrürlü olarak yürütülmüş olup her tekerrürde altı meyve bulunmaktadır. Her bir analiz için ise her tekerrürü temsilen en az üç meyve kullanılmıştır.

Deneme Deseni: Deneme tesadüf parselleri deneme desenine göre 3 tekerrürlü olarak kurulmuş, yürütülmüş ve değerlendirilmiştir. Her tekerrürde 6 meyve (1 paket) kullanılmıştır. Deneme sonuçlarının değerlendirilmesi için SPSS 16 programı ile varyans analizi yapılmış, ortalamalar arasındaki farklılıkları karşılaştırmak için de Duncan karşılaştırma testi kullanılmıştır.

\section{BULGULAR ve TARTIŞMA}

\section{Ağırlık Kaybı}

Genel olarak yaş meyve ve sebzelerde su kaybına bağlı meydana gelen ağırlık kaybı, hem görsel ve kalite kayılarına, hem de ekonomik kayılara neden olmaktadır. Dolayısıyla ağırlık kaybını asgari seviyelerde tutmak başarılı muhafazanın hedefleri arasında yer almaktadır. Mevcut çalışmada kivi meyvelerinde 6 aylık muhafaza sonucunda ortalama olarak yalnızca \%3.41, maksimumda ise \%3.57 oranında ağırlık kaybı meydana gelmiştir (Çizelge 1). Burdon ve Clark (2001) kivilerde meyvelerin \%8-10 arasında ağırlık kaybettiğini bildirmişlerdir. Mevcut çalışmada ise ağırlık kaybı oldukça düşük düzeyde kalmış olup, bunun nedeni kivilerin polimerik film ile ambalajlanmış olmasıdır. Denemede en düşük ağırlık kaybı \%1.44 ile 12 saatlik ozon uygulamasından elde edilirken, en yüksek kayıp \% 1.89 ile kontrol grubunda meydana gelmiş olup, diğer ozon uygulamaları arasında ise \%1.77-1.83 arasında değişmiştir. Dolayısıyla ozon uygulamalarının ağırlık kaybını azaltmada etkili olduğu belirlenmiştir. Yapılan çalışmalarda; kivilerde (Minas ve ark., 2012), papayalarda (Ali ve ark., 2014), çileklerde (Nadas ve ark., 2003) ve dutlarda (Tabakoglu ve Karaca, 2018) ozon gazı uygulamasının meyvelerde etilen üretimini yavaşlatarak, meyvelerin olgunlaşma ve yaşlanmasını geciktirdiği dolayısıyla yaşlanmaya bağlı olarak ağırlık kaybı, suda çözünür kurumadde miktarı (SÇKM), meyve eti sertliği ve mikrobiyolojik bozulma gibi metabolik olaylarda meydana gelen değişimin de azaltıldığı belirlenmiştir. Nitekim mevcut çalışmada da kontrol grubundaki meyvelerin SÇKM miktarı ve meyve eti sertliği, ozon uygulamalarına göre yüksek bulunmuş özellikle 12 saat süreyle ozon uygulanan kivi meyvelerinin SÇKM miktarı ve meyve eti sertliği kontrol grubuna göre önemli oranda düşük bulunmuştur. Dolayısıyla ozon uygulamalarının olgunlaşmayı yavaşlatarak, ağırlı kaybının azaltılmasında etkili olduğu düşünülmüştür. Ayrıca yapılan kolerasyon analizi sonucunda sertlik ve ağırlık kaybı arasında çok kuvvetli negatif $(r=-0,903)$ ilişki olduğu tespit edilmiştir. Dolayısıyla ağırlık kaybının azalması meyve eti sertliğinin ve kalitesinin de korunması anlamına gelmektedir.

\section{Suda Çözünür Toplam Kurumadde (SÇKM) Miktarı}

Yürütülen bu çalışmada depolama başlangıcında \%7.93 olan SÇKM miktarı depolama sonunda \%13.22'e yükselmiş (Çizelge 2) olup, altı aylık depolama süresince toplam \%54 oranında artmıştır. Kivi gibi klimakterik meyvelerde hasattan sonraki olgunlaşma süreci boyunca SÇKM değerinde artış olduğu belirtilmiştir (Bal, 2009; Bolel ve ark., 2019). Bu artışın nedeni olarak olgunluk sürecinde meyve içerisindeki nişastanın çözünebilir şekerlere 
dönüşmesi gösterilmektedir (Karaçalı, 2014). Çalışmada ozon gazı uygulamalarının kontrole göre SÇKM artışını dolayısıyla nişastanın parçalanmasını yavaşlattığ etkinin dozlara göre farklı olduğu, depolamanın ilerleyen dönemlerinde yüksek ve düşük dozların etkisini kaybettiği, buna karşın muhafaza boyunca SÇKM miktarında en az artış gösteren uygulamanın ise 12 saatlik (\%11.83) ozon gazı uygulaması olduğu saptanmıştır.

Çizelge 1. Farklı sürelerde ozon gazı uygulamalarının muhafaza süresince kivi meyvelerinin ağırlık kaybı (\%) üzerine etkileri

Table 1. Effects of ozone gas treatments at different times on weight loss (\%) of kiwi fruits during storage.

\begin{tabular}{lllllllll}
\hline \multirow{2}{*}{$\begin{array}{l}\text { Uygulamalar } \\
\text { Treatments }\end{array}$} & \multicolumn{7}{l}{ Muhafaza Süresi (Ay), Storage Duration (Month) } & \multicolumn{2}{c}{$\begin{array}{c}\text { Uyg ort. } \\
\text { Means of Treatment }\end{array}$} \\
\cline { 2 - 8 } Kontrol & 0 & 1 & 2 & 3 & 4 & 5 & 6 & $1.89 \mathrm{a}$ \\
6 saat & 0 & 0.86 & 1.53 & 1.98 & 2.39 & 2.95 & 3.56 & $1.83 \mathrm{~b}$ \\
12 saat & 0 & 0.60 & 1.47 & 1.94 & 2.36 & 2.91 & 3.54 & $1.44 \mathrm{~d}$ \\
24 saat & 0 & 0.52 & 1.03 & 1.45 & 1.85 & 2.34 & 2.91 & $1.77 \mathrm{c}$ \\
48 saat & 0 & 0.63 & 1.24 & 1.79 & 2.29 & 2.92 & 3.57 & $1.80 \mathrm{bc}$ \\
\hline Zaman ort. & 0 & 0.73 & 1.37 & 1.85 & 2.29 & 2.87 & 3.51 & \\
\hline
\end{tabular}

Çizelge 2. Farklı sürelerde ozon gazı uygulamalarının kivi meyvelerinde muhafaza süresince SÇKM miktarı (\%) üzerine etkileri

Table 2. Effects of ozone gas treatments at different times on the amount of TSS (\%) in kiwifruit during storage

\begin{tabular}{llllllllc}
\hline Uygulamalar & \multicolumn{7}{c}{ Muhafaza Süresi (Ay), Storage Duration (Month) } & Uyg. Ort. \\
\cline { 2 - 8 } Treatments & 0 & 1 & 2 & 3 & 4 & 5 & 6 & Means of Treatments \\
\hline Kontrol & 7.93 & 12.30 & 13.93 & 13.43 & 12.30 & 12.97 & 13.27 & $12.30 \mathrm{a}$ \\
6 saat & 7.93 & 12.03 & 12.90 & 13.53 & 12.80 & 11.83 & 12.97 & $12.00 \mathrm{ab}$ \\
12 saat & 7.93 & 11.70 & 12.57 & 12.70 & 12.43 & 12.53 & 13.00 & $11.83 \mathrm{~b}$ \\
24 saat & 7.93 & 11.77 & 12.77 & 13.07 & 13.00 & 12.93 & 13.30 & $12.10 \mathrm{ab}$ \\
48 saat & 7.93 & 11.87 & 12.83 & 13.17 & 12.97 & 12.53 & 13.57 & $12.12 \mathrm{ab}$ \\
\hline Zaman ort. & $7.93 \mathrm{e}$ & $11.93 \mathrm{~d}$ & $13.00 \mathrm{ab}$ & $13.18 \mathrm{a}$ & $12.70 \mathrm{bc}$ & $12.56 \mathrm{c}$ & $13.22 \mathrm{a}$ & \\
\hline
\end{tabular}

\section{Meyve Eti Sertliği}

Araştırmada, muhafaza süresi başlangıcında $44.11 \mathrm{~N}$ olan meyve eti sertliğinin, 6 aylık muhafaza sonunda \% 90.5 oranında azaldığı bulunmuştur (Çizelge 3). Yumuşamanın temel nedeni olarak kivi meyvelerinde olgunlaşmanın devam etmesi ve bu süreçte oluşan su kaybı gösterilebilir. Çalışmada, meyve eti sertliğinde en fazla azalma kontrol ve 24 saatlik ozon uygulamalarında (15.82 N) meydana gelirken, en düşük azalma $17.29 \mathrm{~N}$ ile 12 saatlik ozon uygulamasında tespit edilmiştir. Elde edilen bu sonuç; Glowacz ve ark. (2015)'nın salatalık ve kabaklarda, Skog ve Chu (2001)'nun salatalarda, Ali ve ark. (2014)'ün papayada, Aguayo ve ark. (2006)'nın domateslerde elde ettiği ozon uygulamalarının meyve eti sertliğini korumada etkili olduğu sonucu ile uyumludur. Ayrıca araştırmada kivi meyvelerinin sertliğinin 1. ayda \%30 oranında, 2.ayda ise \%60 civarında azaldığı belirlenmiştir. Schroeder ve Atkinson (2006) hasattan sonra kivi meyvelerinde sertlik değeri yüksek olmakla birlikte, depolama süresinin başlangiç dönemlerinde özellikle etilen üretiminin artışıyla hızlı bir yumuşama meydana geldiğini belirtmiştir. Dolayısıyla mevcut çalışmada depolamanın ilk iki ayında meyve sertliğindeki hızlı azalma bu görüşle uyuşmaktadır. Ayrıca yapılan korelasyon analizi fruktoz miktariyla meyve eti sertliği $(r=-0,857)$ arasında ters orantının olduğunu, meyvenin olgunlaşmasına paralel olarak fruktoz içeriğinin arttığını, buna karşılık meyve eti sertliğinin azaldığını göstermektedir.

\section{Elektrolit Sizıntısı}

Meyve ve sebzelerde hasat sonrası yapılan uygulamalar zaman zaman hücre duvarında hasarlar meydana getirebilmektedir $\mathrm{Bu}$ hasarın en iyi göstergesi ise hücre duvarından hücre boşluklarına olan elektrolit sızıntısı olarak adlandırılan potasyum iyonu sizıntısıdır (Kasım ve Kasım, 2016). Bu durum daha çok üşüme zararı hassasiyeti olan ürünlerde fizyolojik olarak karşılaşılan bir durum (Halloran ve ark., 1996) olmakla birlikte, herhangi bir nedenle hücre zarar gördüğünde de oluşmakta, ayrıca olgunlaşmaya bağlı olarak da meydana gelebilmektedir. Mevcut çalışmada muhafaza süresi başlangıcında \%30.23 olan sızıntı oranının depolamanın ilk üç ayında yükselmeye başladığı, bu dönemin ardından altıncı ayın sonuna kadar azaldığı ve altıncı ayın sonunda \%43.10'a düştüğü tespit edilmiştir (Çizelge 4). Nitekim hıyarlarda yapılan bir çalışmada muhafaza boyunca ozon gazı uygulamasının elektrolit sızıntısını arttırdığı bildirilmiştir (Çavuşoğlu, 2014). Yapılan ozon uygulamalarından 12 (\%45.04) ve 48 saatlik (\%43.06) uygulamalarm kivilerde elektrolit sızıntısını az oranda arttırdığ görülse de istatistiksel olarak sadece 6 ve 12 saat 
uygulamaları arasındaki fark önemli bulunmuştur. Dolayısıyla eldeki sonuçlara göre ozon uygulamasının doku hasarına neden olduğu söylenemez.

Çizelge 3. Farklı sürelerde ozon gazı uygulamalarının kivi meyvelerinde muhafaza süresince meyve eti sertliği (N) üzerine etkileri

Table 3. Effects of ozone gas treatments at different times on fruit firmness (N) of kiwi fruit during storage.

\begin{tabular}{llllllllc}
\hline $\begin{array}{l}\text { Uygulamalar } \\
\text { Treatments }\end{array}$ & \multicolumn{4}{c}{ Muhafaza Süresi (Ay), Storage Duration (Month) } & \multicolumn{2}{c}{$\begin{array}{c}\text { Uyg ort. } \\
\text { Means of Treatments }\end{array}$} \\
\cline { 2 - 8 } Kontrol & 0 & 1 & 2 & 3 & 4 & 5 & 6 & $15.82 \mathrm{~b}$ \\
6 saat & 44.11 & 28.11 & 13.34 & 8.65 & 6.92 & 5.29 & 4.34 & $16.11 \mathrm{ab}$ \\
12 saat & 44.11 & 30.45 & 14.41 & 8.37 & 6.68 & 4.53 & 4.20 & $17.29 \mathrm{a}$ \\
24 saat & 44.11 & 29.21 & 13.81 & 8.88 & 6.91 & 4.43 & 3.37 & $15.82 \mathrm{~b}$ \\
48 saat & 44.11 & 30.82 & 14.33 & 9.23 & 6.30 & 5.74 & 4.54 & $16.44 \mathrm{ab}$ \\
\hline Zaman ort. & $44.11 \mathrm{a}$ & $30.16 \mathrm{~b}$ & $15.04 \mathrm{c}$ & $8.89 \mathrm{~d}$ & $6.62 \mathrm{e}$ & $5.04 \mathrm{f}$ & $4.21 \mathrm{f}$ & \\
\hline
\end{tabular}

Çizelge 4. Farklı sürelerde ozon gazı uygulamalarının kivi meyvelerinde muhafaza süresince elektrolit sızıntısı (\%) üzerine etkileri

Table 4. Effects of ozone gas treatments at different times on electrolyte leakage (\%) of kiwi fruits during the storage.

\begin{tabular}{|c|c|c|c|c|c|c|c|c|}
\hline \multirow{2}{*}{$\begin{array}{l}\text { Uygulamalar } \\
\text { Treatments } \\
\end{array}$} & \multicolumn{7}{|c|}{ Muhafaza Süresi (Ay), Storage Duration (Month) } & \multirow{2}{*}{$\begin{array}{c}\text { Uyg ort. } \\
\text { Means of Treatments }\end{array}$} \\
\hline & 0 & 1 & 2 & 3 & 4 & 5 & 6 & \\
\hline Kontrol & 30.23 & 34.44 & 38.66 & 52.00 & 51.43 & 44.78 & 43.06 & $42.09 \mathrm{ab}$ \\
\hline 6 saat & 30.23 & 37.35 & 44.47 & 46.79 & 45.80 & 41.97 & 37.72 & $40.62 \mathrm{~b}$ \\
\hline 12 saat & 30.23 & 41.48 & 52.73 & 56.19 & 46.26 & 44.30 & 44.08 & $45.04 \mathrm{a}$ \\
\hline 24 saat & 30.23 & 37.26 & 44.29 & 60.71 & 46.21 & 38.57 & 43.35 & $42.95 \mathrm{ab}$ \\
\hline 48 saat & 30.23 & 39.34 & 48.46 & 55.65 & 42.68 & 37.74 & 47.29 & $43.06 \mathrm{ab}$ \\
\hline Zaman ort. & $30.23 \mathrm{e}$ & $37.98 \mathrm{~d}$ & $45.72 \mathrm{~b}$ & $54.27 \mathrm{a}$ & $46.48 \mathrm{c}$ & $41.47 \mathrm{~cd}$ & $43.10 \mathrm{bc}$ & \\
\hline
\end{tabular}

Titre edilebilir asit (TEA) miktarı

Olgunlaşmaya bağlı olarak meyvenin asit miktarı gittikçe azalmaktadır. Ağaç olumunda hasat edilen kivilerde de muhafaza boyunca TEA miktarinda azalmalar tespit edilmiştir. Kivi meyvelerinin hasat olumundaki TEA değerinin yeme olumundakinin iki katı civarında olduğu, olgunlaşma ile yarı yarıya azaldığı belirtilmiştir (Macrae ve ark., 1987). Özer ve ark. (1997), da depolama süresince üründeki asit miktarında azalmalar olduğunu saptamışlardır. Araştırmada, başlangıçta \%1.58 olan TEA miktarı muhafazanın altıncı ayının sonunda \%1.29'a kadar düşmüştür. Bu da başlangıç değerine göre yaklaşık ortalama \%25 oranında bir azalma meydana geldiğini göstermektedir. Bununla birlikte ozon uygulamalarının titre edilebilir asit üzerine önemli bir etkisi olmadığı bulunmuştur (Çizelge 5). Whangchai ve ark. (2010), 28 gün boyunca günde 2 saat süreyle 200 $\mathrm{mg} / \mathrm{L}$ ozon gazı uygulamasının tangerin meyvelerinde, Minas ve ark., (2018), 0.3 $\mu \mathrm{L} \mathrm{L}^{-1}$ ozon uygulamasının kivi meyvelerinde titre edilebilir asit miktarını etkilemediğini bulmuşlardır. Yapılan çalışmada da her ne kadar titre edilebilir asit miktarı tüm uygulamalarda başlangıç seviyesinin altına düşmüş olmakla birlikte, ozon uygulamalarının kontrolle karşılaştırıldığında bu azalmada önemli bir etkisinin bulunmadığı saptanmıştır.

\section{Şeker Miktarı}

Meyve olgunlaşması sırasında meyvenin şeker miktarının artış gösterme eğiliminde olduğu tespit edilmiştir (Pareek, 2016). Mevcut çalışmada da deneme süresince fruktoz $\% 53$, glikoz \%120 oranında artış gösterirken, sakkaroz miktarı \%62 oranında azalmış, ayrıca deneme başlangıcında \%4.27 olan toplam şeker miktarı da, muhafaza süresi sonunda \%5.92'ye yükselmiştir (Çizelge 6). Dolayısıyla, hasat döneminde meyvede yüksek oranda bulunan nişastanın parçalanarak basit şekerlere dönüşmesi, ek olarak meyvedeki sakarozun da parçalanması sonucu glikoz ve fruktoz miktarının arttığı düşünülmektedir. Nitekim Hawthorne ve Reid (1982)'in çalışması da bu sonucu destekler niteliktedir. Çalışmada, kivi meyvelerinde muhafaza süresince fruktoz ve glikoz miktarı artmakla birlikte en az artışın sırasıyla \%2.42 ve \%1.97 ile 6 saatlik ozon gazı uygulanan kivilerde oluştuğu, bunu \%2.43 ile fruktoz ve \%1.98 glikoz ile 12 saatlik ozon gazı uygulamasının izlediği, en yüksek sakkaroz miktarının ise sirasıyla \%0.70 ile 24 saat $\% 0.68$ ile 12 saat ve 48 saat ozon uygulamalarinda olduğu bulunmuştur. $\mathrm{Bu}$ sonuçlara göre ozon uygulamaları nişastanın şekere dönüşmesine neden olmakla birlikte, uzun süreli uygulamalarda bu etki görülememiştir. Ozon uygulamalarının kivi meyvelerinde olgunlaşmayı önlediği belirlenmiştir (Minas ve ark., 2012; Minas ve ark., 2018).

Yapılan çalışmada da kontrol ile karşılaştırıldığında tüm ozon uygulamalarındaki kivi meyvelerinin sakkaroz miktarının daha yüksek, hatta 24 saat ozon uygulamasında ise önemli oranda yüksek olduğu 
tespit edilmiştir. Sakkaroz, glikoz ve fruktozdan oluşmakta, depolama süresince olgunlaşma ve yaşlanma ile birlikte sakkaroz miktarı, bu iki şekere parçalandığından, azalmaktadır. Çalışmada kontrol meyvelerinde muhafaza süresince sakkaroz miktarının ozon uygulamalarına göre daha fazla azaldığı, glikoz ve fruktoz miktarının da kontrolden düşük olduğu belirlenmiş olup, bu durum ozon uygulamalarının olgunlaşmayı yavaşlatıcı etkisinden kaynaklandığı sonucuna varılmıştır.

Çizelge 5. Farklı sürelerde ozon gazı uygulamalarının kivi meyvelerinde muhafaza süresince titre edilebilir asit (\%) değişimi üzerine etkileri

Table 5. Effects of ozone gas treatments at different times on titratable acid change (\%) in kiwifruit during storage

\begin{tabular}{|c|c|c|c|c|c|c|c|c|}
\hline \multirow{2}{*}{$\begin{array}{l}\text { Uygulamalar } \\
\text { Treatments }\end{array}$} & \multicolumn{7}{|c|}{ Muhafaza Süresi (Ay), Storage Duration (Month) } & \multirow{2}{*}{$\begin{array}{c}\text { Uyg ort. } \\
\text { Means of Treatments }\end{array}$} \\
\hline & 0 & 1 & 2 & 3 & 4 & 5 & 6 & \\
\hline Kontrol & 1.58 & 1.56 & 1.29 & 1.43 & 1.37 & 1.38 & 1.35 & $1.42 \mathrm{a}$ \\
\hline 6 saat & 1.58 & 1.48 & 1.39 & 1.36 & 1.38 & 1.19 & 1.27 & $1.38 \mathrm{a}$ \\
\hline 12 saat & 1.58 & 1.51 & 1.38 & 1.37 & 1.25 & 1.29 & 1.36 & $1.39 \mathrm{a}$ \\
\hline 24 saat & 1.58 & 1.68 & 1.39 & 1.36 & 1.33 & 1.25 & 1.15 & $1.39 \mathrm{a}$ \\
\hline 48 saat & 1.58 & 1.48 & 1.37 & 1.38 & 1.33 & 1.25 & 1.32 & $1.39 \mathrm{a}$ \\
\hline Zaman ort. & $1.58 \mathrm{a}$ & $1.54 \mathrm{a}$ & $1.36 \mathrm{~b}$ & $1.38 \mathrm{~b}$ & $1.33 \mathrm{bc}$ & $1.27 \mathrm{~d}$ & $1.29 \mathrm{~cd}$ & \\
\hline
\end{tabular}

Çizelge 6. Farklı sürelerde ozon gazı uygulamalarının kivi meyvelerinde muhafaza süresince fruktoz, glikoz, sakaroz ve toplam şeker miktarı (\%) üzerine etkileri

Table 6. Effects of ozone gas treatments at different times on fructose, glucose, sucrose, and total sugar content (\%) in kiwi fruit during the storage.

\begin{tabular}{|c|c|c|c|c|c|c|c|c|c|}
\hline & \multirow{2}{*}{$\begin{array}{l}\text { Uygulamalar } \\
\text { Treatments }\end{array}$} & \multicolumn{7}{|c|}{ Muhafaza Süresi (Ay), Storage Duration (Month) } & \multirow{2}{*}{$\begin{array}{c}\text { Uyg. Ort. } \\
\text { Means of Treatments }\end{array}$} \\
\hline & & $\overline{0}$ & 1 & 2 & 3 & 4 & 5 & 6 & \\
\hline \multirow{6}{*}{ 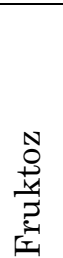 } & Kontrol & 1.90 & 1.99 & 2.51 & 2.64 & 2.84 & 2.55 & 3.32 & $2.54 \mathrm{a}$ \\
\hline & 6 saat & 1.90 & 2.07 & 2.39 & 2.42 & 2.88 & 2.65 & 2.66 & $2.42 \mathrm{~b}$ \\
\hline & 12 saat & 1.90 & 2.05 & 2.43 & 2.43 & 2.64 & 2.72 & 2.88 & $2.43 \mathrm{~b}$ \\
\hline & 24 saat & 1.90 & 2.10 & 2.42 & 2.30 & 2.79 & 2.75 & 3.00 & $2.47 \mathrm{ab}$ \\
\hline & 48 saat & 1.90 & 2.20 & 2.56 & 2.45 & 2.91 & 2.73 & 2.64 & $2.48 \mathrm{ab}$ \\
\hline & Zaman ort. & $1.90 \mathrm{e}$ & $2.08 \mathrm{~d}$ & $2.46 \mathrm{c}$ & $2.45 \mathrm{c}$ & $2.81 \mathrm{a}$ & $2.68 \mathrm{~b}$ & $2.90 \mathrm{a}$ & \\
\hline \multirow{6}{*}{ No } & Kontrol & 1.15 & 1.45 & 1.82 & 1.83 & 2.60 & 2.38 & 2.91 & $2.02 \mathrm{a}$ \\
\hline & 6 saat & 1.15 & 1.49 & 1.76 & 1.75 & 2.82 & 2.43 & 2.39 & $1.97 \mathrm{a}$ \\
\hline & 12 saat & 1.15 & 1.49 & 1.82 & 1.74 & 2.61 & 2.47 & 2.56 & $1.98 \mathrm{a}$ \\
\hline & 24 saat & 1.15 & 1.57 & 1.81 & 1.66 & 2.71 & 2.55 & 2.63 & $2.01 \mathrm{a}$ \\
\hline & 48 saat & 1.15 & 1.60 & 1.94 & 1.80 & 2.94 & 2.52 & 2.29 & $2.03 \mathrm{a}$ \\
\hline & Zaman ort. & $1.15 \mathrm{f}$ & $1.52 \mathrm{e}$ & $1.83 \mathrm{~d}$ & $1.76 \mathrm{~d}$ & $2.74 \mathrm{a}$ & $2.47 \mathrm{c}$ & $2.55 \mathrm{~b}$ & \\
\hline \multirow{6}{*}{ 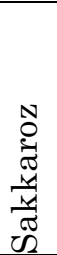 } & Kontrol & 1.23 & 0.75 & 0.50 & 0.40 & 0.57 & 0.50 & 0.48 & $0.63 \mathrm{~b}$ \\
\hline & 6 saat & 1.23 & 0.92 & 0.47 & 0.45 & 0.67 & 0.57 & 0.39 & $0.67 \mathrm{ab}$ \\
\hline & 12 saat & 1.23 & 0.96 & 0.63 & 0.43 & 0.45 & 0.55 & 0.51 & $0.68 \mathrm{ab}$ \\
\hline & 24 saat & 1.23 & 1.01 & 0.54 & 0.40 & 0.53 & 0.58 & 0.57 & $0.70 \mathrm{a}$ \\
\hline & 48 saat & 1.23 & 0.94 & 0.62 & 0.47 & 0.62 & 0.53 & 0.39 & $0.68 \mathrm{ab}$ \\
\hline & Zaman ort. & $1.23 \mathrm{a}$ & $0.92 \mathrm{~b}$ & $0.55 \mathrm{c}$ & $0.43 \mathrm{~d}$ & $0.57 \mathrm{c}$ & $0.54 \mathrm{c}$ & $0.47 \mathrm{~d}$ & \\
\hline \multirow{6}{*}{ 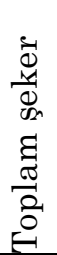 } & Kontrol & 4.27 & 4.20 & 4.83 & 4.87 & 6.02 & 5.43 & 6.71 & $5.19 \mathrm{a}$ \\
\hline & 6 saat & 4.27 & 4.49 & 4.62 & 4.62 & 6.36 & 5.65 & 5.44 & $5.06 \mathrm{a}$ \\
\hline & 12 saat & 4.27 & 4.50 & 4.88 & 4.60 & 5.69 & 5.73 & 5.95 & $5.09 \mathrm{a}$ \\
\hline & 24 saat & 4.27 & 4.68 & 4.77 & 4.37 & 6.04 & 5.88 & 6.20 & $5.17 \mathrm{a}$ \\
\hline & 48 saat & 4.27 & 4.74 & 5.12 & 4.72 & 6.47 & 5.78 & 5.31 & $5.20 \mathrm{a}$ \\
\hline & Zaman ort. & $4.27 \mathrm{f}$ & $4.52 \mathrm{e}$ & $4.84 \mathrm{~d}$ & $4.64 \mathrm{e}$ & $6.12 \mathrm{a}$ & $5.69 \mathrm{c}$ & $5.92 \mathrm{~b}$ & \\
\hline
\end{tabular}

\section{Toplam Klorofil Miktarı}

Meyvelerde bulunan klorofil miktarının, gelişme döneminin başlarında maksimum seviyedeyken daha sonra azaldığ sürekli azalma gösterdiği belirtilmiştir. Bu azalışın nedeninin hem meyve yüzeyinin genişlemesi hem de klorofil parçalanması olduğu ifade edilmiştir (Karaçalı 2014). Ayrıca klorofil kaybının düşük sıcaklıkta bile devam ettiği ve uzun süre depolanan meyve ve sebzelerinde yeşil renginin kaybolduğu ifade edilmiştir (Bal, 2009). Çalışmada kullanılan yeşil meyve etine sahip Hayward çeşidinde muhafazanın ilk aylarında yüksek olan toplam klorofil seviyesi deneme sonuna kadar azalma göstermiştir (Çizelge 7). Karakurt ve Aslantaş (2008) klorofilin ışıksız ortamlarda ve hasat sonrası bekleme koşullarında ve yaşlanma ile birlikte 
kayba uğradığını; Çavuşoğlu (2014) brokkolide, Kasım ve Kasım (2016) ise sspanakta hasat sonrası dönemde klorofil kaybı meydana geldiğini bulmuşladır. Çalışmada genel olarak klorofil miktarı tüm uygulamalarda azalmakla birlikte, ozon uygulanan kivilerde kontrole göre daha düşük olduğu bulunmuştur. Özellikle 48 saatlik (38.18) ozon uygulaması yapılan kivilerin klorofil miktarı diğer uygulamalardan oldukça düşüktür. $\mathrm{Bu}$ da ozon uygulama dozunun artmasinın meyvelerde klorofil parçalanmasına neden olduğunu göstermektedir. Nitekim, ozon gazının yeşil renkli ürünlerde klorofil parçalanmasına neden olmasinın en önemli dezavantajı olduğu belirtilmiştir (Horvitz ve Cantalejo, 2014).

Çizelge 7. Farklı sürelerde ozon gazı uygulamalarının kivi meyvelerinde muhafaza süresince Toplam klorofil üzerine etkileri

Table 7. Effects of ozone gas treatments at different times on total chlorophyll content of kiwi fruits during the storage

\begin{tabular}{|c|c|c|c|c|c|c|c|c|}
\hline \multirow{2}{*}{$\begin{array}{l}\text { Uygulamalar } \\
\text { Treatments }\end{array}$} & \multicolumn{7}{|c|}{ Muhafaza Süresi (Ay), Storage Duration (Month) } & \multirow{2}{*}{$\begin{array}{c}\text { Uyg ort. } \\
\text { Means of Treatments }\end{array}$} \\
\hline & 0 & 1 & 2 & 3 & 4 & 5 & 6 & \\
\hline Kontrol & 96.11 & 122.26 & 47.68 & 62.76 & 11.82 & 21.88 & 5.58 & $52.58 \mathrm{a}$ \\
\hline 6 saat & 96.11 & 82.89 & 64.27 & 15.91 & 10.24 & 23.14 & 17.07 & $44.23 \mathrm{ab}$ \\
\hline 12 saat & 96.11 & 111.19 & 49.92 & 15.51 & 10.64 & 17.73 & 18.09 & $45.60 \mathrm{ab}$ \\
\hline 24 saat & 96.11 & 127.64 & 71.07 & 16.66 & 11.60 & 13.35 & 9.53 & $50.28 \mathrm{ab}$ \\
\hline 48 saat & 96.11 & 57.44 & 50.49 & 11.10 & 14.37 & 13.37 & 24.42 & $38.18 \mathrm{~b}$ \\
\hline Zaman ort. & $96.11 \mathrm{a}$ & $100.28 \mathrm{a}$ & $56.68 b$ & $24.39 \mathrm{c}$ & $12.93 \mathrm{c}$ & $17.89 \mathrm{c}$ & $14.94 \mathrm{c}$ & \\
\hline
\end{tabular}

\section{Meyve Kabuk Rengi}

Ürünün görsel kalitesi; herhangi bir renk değişikliği tüketiciler tarafindan yaşlanma belirtisi olarak algılanabildiği için önemlidir (Nunes ve ark., 2009). Özellikle ürünün parlaklığı $\left(L^{*}\right)$ bu açıdan daha da öne çıkmaktadır. Mevcut çalışmada muhafaza başlangıcında 48.19 olarak ölçülen $L^{*}$ değerinin muhafazanın ikinci ayında artmasına karşılık (48.71, Çizelge 8) muhafaza sonunda 45.30'a düştüğü tespit edilmiş olup, ozon uygulamalarının parlaklık üzerine etkisi ise istatistiki olarak önemli bulunmuştur. Parlaklığın korunması açısından $48(47,23)$ ve 12 saat $(47,21)$ ozon uygulamalarının daha etkili olduğu; 24 saatlik $(46,61)$ ozon uygulaması ve kontrol grubu (47.06)'ndaki kivilerinin parlaklık değerlerinin ise daha az olduğu belirlenmiştir. Araştırmada, en yüksek $a$ * değeri $(3,86)$ kontrol grubundaki kivi meyvelerinde ölçülürken, en düşük değer 48 saatlik (3.67) ozon uygulamasından elde edilmiştir (Çizelge 8). Çalışmada elde edilen $a^{*}$ değeri sonuçları ile $L^{*}$ değeri sonuçları birbirini destekler niteliktedir. Araştırmada, meyvelerin $b^{*}$ renk değerlerinin genel olarak azaldığ ve meyve kabuk renginin sarıdan, açık sarı renge doğru değiştiği gözlemlenmiştir. Denemede en yüksek $b^{*}$ değeri kontrol grubu (27.18) ve 6 saatlik (27.14) ozon uygulamasında ölçülmüştür. Çalışmada ölçülen $L^{*}$ ve $b^{*}$ değerlerindeki azalma, meyve kabuğu renginin koyulaştığının bir göstergesi olarak düşünülebilir. Yapılan çalışmalarda yüksek dozda ozon gazı kullanımının ürünlerin rengini olumsuz etkilediği (Ekici ve ark., 2006), kirazlarda ise renk açılmalarına neden olduğu bildirilmiştir (Çağatay, 2006). Mevcut çalışmada ise kivi kabuğu üzerindeki tüylerden dolayı ozon gazının kabuk rengi üzerinde olumsuz bir etkisinin olmadığı düşünülmektedir.

\section{Tat Puanlaması}

Araştırmada, kivi meyvelerinde muhafaza boyunca şeker miktarının yükselirken, asit oranının azalması tadım testinde etkili bir kriter olmuştur. Genel olarak depolama süresince tüm uygulamalarda tat puanlarının arttığı görülmektedir (Çizelge 9). Buna karşılık, ozon uygulanan kivi meyvelerinin tat puanlarının özellikle muhafazanın ilk dört ayı boyunca kontrol grubuna göre daha yüksek olduğu belirlenmiştir. Muhafaza süresinin sonunda ise en yüksek tat puanı 4.08 ile 48 saatlik ozon uygulamasından elde edilirken, en düşük tat puanları 24 saatlik uygulamada bulunmuştur. Tat puanları açısından 48 saat ozon uygulaması ile kontrol grubu arasındaki farklllık istatistiki düzeyde anlamlı bulunurken, ozon uygulamaları arasındaki farklılığın önemsiz olduğu tespit edilmiştir. Ozon uygulamaları ile meyvelerin tat özelliklerinde özellikle aromalarında kayıpların meydana geldiği ifade edilmektedir. $\mathrm{Bu}$ kayıpların uçucu bileşiklerin emisyonunun azaltılmasından kaynaklandığı bildirilmiştir (Miller ve ark., 2013). Nitekim yapılan çalışmalarda, Nadas ve ark., 2003) $1.5 \mu \mathrm{L} \mathrm{L} \mathrm{L}^{-1}$ ozon içeren soğuk odada $\left(2^{\circ} \mathrm{C}\right)$ depolanıp oda sıcaklığına alınan çileklerin meyve aromasında geri dönüşümlü bir kayba yol açtığını ve bu olayın meyve tarafından salınan uçucu bileşiklerin oksidasyonundan kaynaklandığını ileri sürmüşlerdir. Perez ve ark. (1999) ise 0,35 ppm ozon içeren $\operatorname{soğuk}\left(2^{\circ} \mathrm{C}\right)$ ortamda üç gün depolandıktan sonra $20^{\circ} \mathrm{C}$ sıcaklıkta dört gün tutulan çilek meyvelerinin uçucu ester emisyonunda\% 40'llk bir azalma olduğunu tespit etmişlerdir. Araştırmada ise ozon uygulamalarının tat kalitesi üzerine olumsuz bir etkisi bulunmadığ görülmüştür. $\mathrm{Bu}$ sonucun ise uygulanan dozun diğer araştırıcıların uyguladıkları dozlara göre nispeten düşük kalması nedeniyle olduğu söylenebilir. 
Çizelge 8. Farklı sürelerde ozon gazı uygulamalarının kivi meyvelerinde muhafaza süresince Meyve kabuk rengindeki değişimler üzerine etkileri

Table 8. Effects of ozone gas treatments at different times on changes in fruit skin color during the storage of kiwi fruit

\begin{tabular}{|c|c|c|c|c|c|c|c|c|c|}
\hline & \multirow{2}{*}{$\begin{array}{l}\text { Uygulamalar } \\
\text { Treatments }\end{array}$} & \multicolumn{7}{|c|}{ Muhafaza Süresi (Ay), Storage Duration (Month) } & \multirow{2}{*}{$\begin{array}{c}\text { Uyg. Ort. } \\
\text { Means of Treatments }\end{array}$} \\
\hline & & 0 & 1 & 2 & 3 & 4 & 5 & 6 & \\
\hline \multirow{6}{*}{$\begin{array}{l}0 \\
0 \\
0 \\
0 \\
0 \\
* \\
*\end{array}$} & Kontrol & 48.19 & 48.75 & 47.34 & 47.46 & 46.86 & 45.96 & 44.88 & $47.06 \mathrm{a}$ \\
\hline & 6 saat & 48.19 & 48.57 & 47.83 & 47.07 & 46.02 & 46.43 & 45.98 & $47.15 \mathrm{a}$ \\
\hline & 12 saat & 48.19 & 48.70 & 47.20 & 47.20 & 47.30 & 46.19 & 45.71 & $47.21 \mathrm{a}$ \\
\hline & 24 saat & 48.19 & 49.08 & 45.35 & 47.41 & 46.40 & 45.61 & 44.24 & $46.61 \mathrm{~b}$ \\
\hline & 48 saat & 48.19 & 48.46 & 46.50 & 47.07 & 47.30 & 47.41 & 45.67 & $47.23 \mathrm{a}$ \\
\hline & Zaman Ort. & $48.19 \mathrm{~b}$ & $48.71 \mathrm{a}$ & $46.84 \mathrm{~cd}$ & $47.24 \mathrm{c}$ & $46.78 \mathrm{~cd}$ & $46.32 \mathrm{~d}$ & $45.30 \mathrm{e}$ & \\
\hline \multirow{6}{*}{$\begin{array}{l}0 \\
\overline{0} \\
0 \\
0 \\
0 \\
0 \\
* \\
0 \\
0\end{array}$} & Kontrol & 2.16 & 3.08 & 4.06 & 4.19 & 4.43 & 4.47 & 4.63 & $3.86 \mathrm{a}$ \\
\hline & 6 saat & 2.16 & 3.69 & 3.57 & 4.15 & 4.31 & 4.13 & 4.51 & $3.79 \mathrm{a}$ \\
\hline & 12 saat & 2.16 & 3.32 & 3.74 & 3.74 & 4.23 & 4.38 & 4.44 & $3.72 \mathrm{a}$ \\
\hline & 24 saat & 2.16 & 2.80 & 3.83 & 3.83 & 4.21 & 4.41 & 4.50 & $3.68 \mathrm{a}$ \\
\hline & 48 saat & 2.16 & 3.42 & 3.70 & 3.87 & 4.10 & 3.78 & 4.61 & $3.67 \mathrm{a}$ \\
\hline & Zaman Ort. & $2.16 \mathrm{e}$ & $3.27 \mathrm{~d}$ & $3.78 \mathrm{c}$ & $3.96 \mathrm{~b}$ & $4.26 \mathrm{~b}$ & $4.24 \mathrm{~b}$ & $4.54 \mathrm{a}$ & \\
\hline \multirow{6}{*}{ 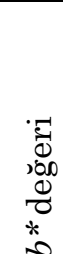 } & Kontrol & 30.37 & 28.16 & 26.60 & 26.70 & 26.09 & 26.12 & 26.21 & $27.18 \mathrm{a}$ \\
\hline & 6 saat & 30.37 & 27.92 & 27.04 & 26.00 & 26.17 & 26.00 & 26.48 & $27.14 \mathrm{a}$ \\
\hline & 12 saat & 30.37 & 26.82 & 25.88 & 25.89 & 25.96 & 25.98 & 26.76 & $26.81 \mathrm{ab}$ \\
\hline & 24 saat & 30.37 & 26.71 & 25.78 & 26.26 & 25.89 & 25.69 & 24.60 & $26.47 \mathrm{~b}$ \\
\hline & 48 saat & 30.37 & 26.67 & 26.56 & 25.88 & 26.82 & 27.14 & 26.81 & $27.18 \mathrm{a}$ \\
\hline & $\mathrm{ZaI}$ & 30 & $27.26 \mathrm{~b}$ & 26 & $26.15 \mathrm{c}$ & $26.18 \mathrm{c}$ & $26.19 \mathrm{c}$ & $26.17 \mathrm{c}$ & \\
\hline
\end{tabular}

Çizelge 9. Farklı sürelerde ozon gazı uygulamalarının kivi meyvelerinde muhafaza süresince tat puanlarındaki değişimler üzerine etkileri

Table 9. ffects of ozone gas treatments at different times on changes in taste scores during storage of kiwi fruits

\begin{tabular}{lllllll}
\hline $\begin{array}{l}\text { Uygulamalar } \\
\text { Treatments }\end{array}$ & \multicolumn{4}{c}{ Muhafaza Süresi (Ay), Storage Duration (Month) } & Uyg. Ort. \\
\cline { 2 - 6 } & 2 & 3 & 4 & 5 & 6 & Means of Treatments \\
\hline Kontrol & 3.63 & 3.67 & 2.33 & 3.78 & 3.67 & $3.42 \mathrm{~b}$ \\
6 saat & 4.1 & 4.33 & 4.00 & 3.55 & 3.17 & $3.83 \mathrm{ab}$ \\
12 saat & 4.3 & 4.00 & 3.33 & 3.33 & 3.92 & $3.78 \mathrm{ab}$ \\
24 saat & 4.43 & 3.83 & 5.00 & 3.55 & 2.17 & $3.0 \mathrm{ab}$ \\
48 saat & 4.63 & 4.50 & 3.33 & 4.55 & 4.08 & $4.22 \mathrm{a}$ \\
\hline Zaman ort. & $4.22 \mathrm{a}$ & $4.07 \mathrm{ab}$ & $3.60 \mathrm{c}$ & $3.75 \mathrm{bc}$ & $3.40 \mathrm{c}$ & $4.22 \mathrm{a}$ \\
\hline
\end{tabular}

\section{SONUÇ}

Farklı sürelerde ozon gazı uygulamalarının muhafaza sirasında kivilerin kalitesi üzerine etkilerini incelemek üzere yürütülen bu çalışmada kivi meyvelerine hasattan sonra 12 saat süreyle ozon gazı uygulamasının; her ne kadar tat üzerine diğer ozon uygulamaları kadar olumlu etkide bulunmamasina karşılık yumuşamayı geciktirmede, ağırlık kaybını azaltmada, SÇKM değişimini ve şeker metabolizmasını yavaşlatmada, dolayısıyla olgunlaşmayı geciktirmede etkili olduğu saptanmıştır. $\mathrm{Bu}$ nedenle ozon gazı uygulamaları arasında 12 saat süreyle yapılan uygulamanın, kivi muhafazasında kullanılabileceği sonucuna varılmıştır.

\section{TEŞEKKÜR}

Bu çalışmayı 2017/096 numara ile destekleyen Kocaeli Üniversitesi Bilimsel Araştırma Projeleri Koordinasyon Birimine teşekkür ederiz.

\section{Çıkar Çatışması Beyanı}

Makale yazarları aralarında herhangi bir çıkar çatışması olmadığını beyan ederler.

\section{Araştırmacıların Katkı Oranı Beyan Özeti}

Yazarlardan Kübra Yaşar, makaleye \%50; M.Ufuk Kasım, makaleye \%35 ve Rezzan Kasım, makaleye \%15 oranda katkı sağlamış olduklarını beyan ederler.

\section{KAYNAKLAR}

Aguayo E, Escalona VH, Artes F 2006. Effect of Cyclic Exposure to Ozone Gas Onphysicochemical, Sensorial and Microbial Quality of Whole and Sliced Tomatoes. Postharvest Biol. Technol 39:169177.

Alexandre EM, Santos-Pedro DM, Brandão TR, Silva CL 2011. Influence of Aqueous Ozone, Blanching and Combined Treatments on Microbial Load of Red Bell Peppers, Strawberries and Watercress. 
Journal of Food Engineering 105(2): 277-282.

Ali A, Ong MK, Forney CF 2014. Effect of Ozone PreConditioning on Quality and Antioxidant Capacity of Papaya Fruit During Ambient Storage. Food Chemistry 142:19-26.

Bal E 2009. Hasat Sonrası Potasyum Permanganat, UV-C, Salisilik Asit Ve Sicaklık Uygulamalarının Kivi Kalitesi ve Muhafaza Süresi Üzerine Etkileri. Tekirdağ: Namık Kemal Üniversitesi Fen Bilimleri Enstitüsü Bahçe Bitkileri Ana Bilim Dalı (Doktora Tezi), 131s.

Bolel H, Koyuncu MA, Erbaş D 2019. Ozon ve Fungusit Uygulamalarının Narda Soğukta Depolama Boyunca Meyve Kalitesi Değişimi Üzerine Etkileri. Iğdır Üniversitesi Fen Bilimleri Enstitüsü Dergisi 9(4): 1841-1850.

Burdon J, Clark C 2001. Effect of Postharvest Water Loss on 'Hayward' Kiwifruit Water Status. Postharvest Biology and Technology 22(3): 215-225.

Çağatay Ö 2006. Ozon uygulamasının adı Kirazın Soğukta Depolanma süresiÜzerine Etkisi. Isparta: Süleyman Demirel Üniversitesi Fen Bilimleri Enstitüsü Bahçe Bitkileri Ana Bilim Dalı (Yüksek Lisans Tezi), 52s.

Çavuşoğlu G 2014. Farklı Doz Ozon Gazı Uygulamalarının Hasat Sonrası Soğukta Saklama Sirasında Brokoli, Salatalık ve Domates Kalitesi Üzerindeki Etkisinin İncelenmesi. İstanbul Teknik Üniversitesi Fen Bilimleri Enstitü Gıda Mühendisliği Ana Bilim Dalı (Yüksek Lisans Tezi), $113 \mathrm{~s}$.

Çelikel FG 2018. Organik Bahçe Ürünlerinin Hasat Sonrası Kalitelerinin Korunması. Türk TarımGida Bilim ve Teknoloji Dergisi 6(2): 175-182.

Dinçer C, Topuz A 2006. Meyve ve Sebzelerin Muhafazasında İyonize Radyasyon Kullanımı. Türkiye 9. Gıda Kongresi s. 285-288.

Ekici L, Sağdıç O, Kesmen Z 2006. Gıda Endüstrisinde Alternatif Bir Dezenfektan: Ozon. Gida Teknolojileri Elektronik Dergisi:1: 47-57.

FAO 2018. FAOSTAT. FAO: http://www.fao.org/ faostat/en/\#home

Feliziani E, Romanazzi G, Smilanick JL 2014. Application of Low Concentrations of Ozone During the Cold Storage of Table Grapes. Postharvest Biol. Technol 93: 38-48.

Garcia CV, Quek SY, Stevenson, RJ, Winz RA 2012. Characterisation of Bound Volatile Compounds of a Low Flavour Kiwifruit Sspecies: Actinidia eriantha. Food Chemistry, 134(2): 655-661.

Glowacz M, Colgan R, Rees D 2015. Influence of Continuous Exposure to Gaseous Ozone on the Quality of Red Bell Peppers, Cucumbers and Zucchini. Postharvest Biol Technol, 99: 1-8.

Halloran N, Cağıran R, Kasım MU 1996. Sebzelerde Hasat Sonrası Üsüme Zararı. Gıda, 21(5):359-366.

Hawthorne BT, Reid MS 1982. Possibility for Fungicidal Control of Kiwifruit Fungal Storage
Rots. New Zealand journal of experimental agriculture 10(3): 333-336.

Horvitz S, Cantalejo MJ 2014. Application Of Ozone For The Postharvest Treatment Of Fruits And Vegetables. Critical Reviews in Food Science And Nutrition, 54(3): 312-339.

Karaçalı İ 2014. Bahçe Ürünlerinin Muhafaza ve Pazarlanması. Ege Üniversitesi Ziraat Fakültesi Yayınları, No:494, 481sy.

Karakurt H, Aslantaş R 2008. Bitki Renk Maddelerinin (Pigmentler) Oluşum ve Değişim Fizyolojisi. Alatarım, 7 (2): 34-41.

Kasim MU, Kasim R 2015. Postharvest UV-B Treatments Increased Fructose Content of Tomato (Solanum lycopersicon L. cv. Tayfun F1) Harvested at Different Ripening Stages. Food Science and Technology Campinas, 35(4): 742-749.

Kasım MU, Kasım R 2016. Taze Kesilmiş Ispanaklarda Farklı Dalga Boyundaki Ultraviyole Işınlarının Hasat Sonrası Kaliteye Etkisi. YYÜ Tar.Bil.Dergisi 26(3): 348-359.

Macrae EA, Bowen JH, Stec MG 1987. Maturation of Kiwifruit (Actinidia deliciosa cv Hayward) from two Orchards: Differences in Composition of the Tissue Zones. Journal of the Science of Food and Agriculture, 47(4): 401-416.

Mencarelli F, Saltveit MJ 1988. Ripening of MatureGreen Tomato. Journal of The American Society for Horticultural Science, 122: 594-598.

Minas IS Tanou G, Belghazi M, Job D, Manganaris GA, Molassiotis A 2012. Physiological and Proteomic Approaches to Address the Active Role of Ozone in Kiwifruit Postharvest Ripening. Journal of Experimental Botany, 63(7): 2449-2464.

Minas IS, Tanou G, Krokida A, Karagiannis E, Belghazi M, Vasilakakis M, Papadopoulou KK, Molassiotis A. 2018. Ozone-Induced Inhibition of Kiwifruit Ripening is Amplified by 1mMthylcyclopropene and Reversed by Exogenous Ethylene. BMC Plant Biology, 18:358:1-19.

Nadas A, Olmo M, García JM 2003. Growth of Botrytis cinerea and Strawberry Quality in Ozone enriched Atmospheres. Journal of Food Science, 68: 7981802.

Nunes MC, Emond JP, Rauth M, Dea S, Chau KV 2009. Environmental Conditions Encountered During Typical Consumer Retail Display Affect Fruit and Vegetable Quality and Waste. Postharvest Biology and Technology, 51(2): 232241.

Özer MH, Eriş A, Türk R, Sivritepe N 1997. Normal, Modifiye ve Kontrollü Atmosfer Koşullarında Muhafaza Edilen Kivilerde Biyokimyasal Değişimler ve Kalite Kayıpları. Bahçe Ürünlerinde Muhafaza ve Pazarlama Sempozyumu, 21-24 Ekim 1997, Yalova. s:125-134.

Pareek S 2016. Ripening physiology: An overview. Postharvest Ripening Physiology of Crops, 1st ed.; 
Pareek, S., Ed, 1-48.

Perez AG, Sanz C, Rios JJ, Olias R, Olias JM (1999) Effects ofozone treatment on postharvest strawberry quality. J Agric FoodChem 47(4):16521656.

Savaş E, Tavşanlı H, Gökgözoğlu İ 2014. Gıda Endüstrisinde Ozon Uygulamaları. Türk TarımGıda Bilim ve Teknoloji Dergisi, 2(3): 122-127.

Servili A, Feliziani E, Romanazzi G. 2017. Exposure to Volatiles of Essential Oils Alone or Under Hypobaric Treatment to Control Postharvest Gray Mold of Table Grapes, Postharvest Biology and Technology. (133): 36-40.

Schroeder R, Atkinson RG 2006. Kiwifruit cell walls: Towards an understanding of softening? New Zealand Journal of Forestry Science 36(1): 112-129.

Sholberg PL, Conway WS 2016. Postharvest Pathology. (Ed. KC Gross, YW Chien, S Mikal) The Commercial Storage of Fruits, Vegetables, and Florist and Nursery Stocks, s. 111-127.

Skog LJ, Chu CL 2001. Effect of ozone on qualities of fruits and vegetables in cold storage. Canadian Journal of Plant Science 81: 773-778.

Souza LP, Faroni LR, Heleno FF, Cecon PR, Gonçalves
TD, Silva GJ 2018. Effects of ozone treatment on postharvest carrot quality. $L W T$ Food Science and Technology 90: 53-60.

Tabakoglu N, Karaca H 2018. Effects of ozone-enriched storage atmosphere on postharvest quality of black mulberry fruits (Morus nigra L.). LWT, 92: 276-281.

USDA., Erişim Tarihi: 1 Nisan 2018, United States Department of Agriculture Agricultural Research Service . adresinden alınmıştır.

Whangchai K, Saengnil K, Singkamanee C, Uthaibutra J. 2010. Effect of Electrolyzed Oxidizing Water and Continuous Ozone Exposure on the Control of Penicillium Digitatum on Tangerine cv. 'Sai Nam Pung' during Storage. Crop Protection, 29(4):386-389.

Yıldız PO Yangilar F 2014. Ozon ve Gida Endüstrisinde Kullanım Alanları. Bülent Ecevit Üniversitesi Fen Bilimleri Dergisi, 3(1): 94-101.

Yılmaz F, Kasım MU, Koşumcu S, Kasım R. 2019. Çilekte (Fragaria x ananassa Duch.) Hasat Sonrası Enfeksiyon ve Kalite Üzerine Bazı Uçucu Yağların Etkisi. Kocaeli Üniversitesi Fen Bilimleri Dergisi, 2(1): 27-35. 